Covered in: Web of Science (WOS); EBSCO; ERIH+; Google Scholar; Index Copernicus; Ideas RePeC; Econpapers; Socionet; CEEOL; Ulrich ProQuest; Cabell, Journalseek; Scipio; Philpapers; SHERPA/RoMEO repositories; KVK; WorldCat; CrossRef; CrossCheck

2021, Volume 12, Issue 3, pages: 230-244 | https://doi.org/10.18662/po/12.3/337

\section{Misinformation in the Information Space of Ukrainian Society during the Covid-19 Pandemic}

\author{
Iryna DENYSENKO', \\ Olena SKALATSKA², \\ Oleg PARKHITKO ${ }^{3}$
}

${ }^{1}$ Doctor of Philosophical Science, Professor, Chair of Faculty of Psychology and Sociology, G.S. Scovoroda Kharkiv National Pedagogical University, Kharkiv, Ukraine, irdden@gmail.com

${ }^{2}$ Doctor of Philosophical Science, Assistant Professor of the Journalism Chair, National University «Odesa Law Academy», Odesa, Ukraine, elena-s2008@ukr.net

${ }^{3} \mathrm{PhD}$ (Philology), Assistant Professor of the Journalism Chair, National University «Odesa Law Academy», Odesa, Ukraine, fianketto79@gmail.com
Abstract: The specificity of misinformation about Covid-19 which was outspread in the media landscape of Ukrainian society was demonstrated in the article. The authors relying on the basics of postmodern theory within interdisciplinary discourse trace the means of forming misinformation and its influence on changing worldview landmarks of humanity. The authors underline that information in the postmodern conception of Jean Baudrillard is also capable to destroy its own content, communication and social ground. Misinformation about Covid-19 is «a stage setting of communication» since it only creates insight into sense and is outspreaded with different channels (traditional and new media) with usage of photographic and video materials, emotional headlines and messages. Fake materials which have been outspreaded in online media and social networks are analyzed in the article. The authors found out that fake messages outspreaded in Ukrainian media refer to the following topic (the origin of Covid-19; frauds under the guise of doctors try to get the money of nationals; fictional money penalties for breaking the rules of quarantine; pseudomedical recommendations for taking some medicines and means of diagnosis Covid-19; statements of public authorities about strengthening the regime of quarantine; the speed of spreading Covid-19 in other countries; insufficient readiness of the Ukrainian society to Covid-19, etc.). It is stated that quick expansion of misinformation was facilitated by the fact that the nationals of Ukraine took information without criticism, without fact-checking, since they moved to a new space of life of individual and made «a stage setting of sense».

Keywords: communication; Covid-19; infodemia; media; misinformation; social networks; Ukrainian society.

How to cite: Denysenko, I., Skalatska, O., \& Parkhitko, O. (2021). Misinformation in the Information Space of Ukrainian Society during the Covid-19 Pandemic. Postmodern Openings, 12(3), 230-244. https://doi.org/10.18662/po/12.3/337 


\section{Introduction}

The formation of a postmodern society creates a new social and philosophical discourse when the development of society is being studied on the theoretical foundations of the information society concepts. The significant changes of social reality require some new methodological approaches. New theories of social reality deny consistency, integrity, and they define reality as a plurality of different events and elements. The world is no longer homogeneous, it is full of new opportunities and options. Ideals, and the ideals of social development and progress as well, lose their significance in a postmodern society, and all changes are multivariate in it.

The significance of information in the life of society and a person's life has become one of the most important issues that is actualized in the postmodern society. This issue has become important due to a number of social processes: the social media institute is not only the source of information about social events, but is also a means of influencing public opinion; new channels of communication are constantly under creation; information is available to the general public; the amount and types of misinformation are constantly being increased; the spread of information and misinformation is being accelerated. The phenomenon of "commercial material", "fake news" has become common in the mass consciousness, the public realize that some media reports are aimed at shaping a certain opinion or behavior, or concealing the truth, hiding some more important events.

The research and scientific discussions about the influence of misinformation on society take place in the field of multidisciplinary research among the academic community; and directly among those who create and spread the information, i.e. journalists. The specialists of social communication and practicing journalists are focusing on the questions of anti-fake technologies, information verification, or disinformation recognition trainings for the audience.

Empirical material is a source of theoretical concepts of disinformation. One of the main questions and also the gap of scientific achievements is the problem to predict the appearance of false information in various public spheres. And this despite the fact that the prevention mechanisms of spreading disinformation have been introduced at the state level in many countries of the world, and public relations and the public informing have also been improved. All these measures are constantly faced with new information challenges, which emphasize the need for a culture of 
critical thinking and changes in the individual's literacy of consumption and distribution of information.

The Covid-19 pandemic has become a challenge for modern society, from the medical field it has spread to all spheres of public life and transformed a number of common social practices of individuals. Within the interdisciplinary discourse, scientists will try to justify the impact and predict changes in the worldview of mankind. We believe that this discussion should be based on the main tenets of postmodernism and, in fact, with an emphasis on accelerating the pace of information dissemination.

The source of the Covid-19 problem was medical assumptions common in the information space. At a time when doctors could not determine the origin of the new disease and establish a scheme to combat it according to the symptoms, world news agencies and the media disseminated any information about the new virus describing it as "unknown form of pneumonia", "pneumonia of unknown origin", "unidentified pneumonia" and others. Each country in the world not only set limits, but also informed the population about the number of infected, dead and those who were cured of the disease. Simultaneously with this information, videos, photos and texts which emotionally described the consequences of the disease were spread on social networks. Misleading information began to appear among the news reports, which inflated the situation and intimidated the population. Over time, the number of fake news only increased, which required intervention to prevent its spread and impact.

Social practices of an individual's daily life were limited to quarantine requirements, among which the key ones were social distance, self-isolation, prohibition of holding mass events, wearing protective masks and gloves in public places. Libraries, archives, and museums around the world have allowed free access to their Internet resources; theaters and musicians have started giving online performances; specialists in various fields conducted free online workshops. Thus, the variety of online classes has created the conditions for a new space that existed alongside impressive statistics on the spread and course of Covid-19 disease. Life in real space has been replaced by empty streets and constant restrictions, closed borders and entertainment venues. All life froze, the world slowed down the pace of development, production, consumption.

Individuals whose lives have changed because of the new living conditions have followed the news of Covid-19, which has become so numerous and that is not always true; sometimes the amount of 
misinformation combined with the unknown created a new feature of this process. The concept of "infodemia" appears, which more clearly characterizes this power of informational influence on the behavior of the audience.

The article will show what misinformation about Covid-19 appeared and was spread in the information space of Ukrainian society.

\section{The specifity of misinformation in a postmodern society}

The theoretical foundations of the study of disinformation are the concepts of the information society. American sociologist A. Toffler states, that it takes place the simplification of information production, the phenomenon of media demassification, that "new forms of audio communication take away what's left of the mass audience" during the third wave of the development of society (Toffler, 1980, p. 781).

In the information society, the targets of disinformation in media politics are the political goals and propaganda. Spanish sociologist M. Castells using the example of the war in Iraq analyzed the process of spreading disinformation, the lack of awareness of the main part of society, and the formation of misconceptions about the war, as well as the consequences of such imprecise information, its influence on social institutions. M. Castells finds out the reasons for these processes in the fact that "people are ready to believe in what they want to believe". They filter the information to adapt it to the judgments chosen themselves. They are ready to accept the facts that can challenge their beliefs much less than those that correspond to their ideas. The sociologist concludes that "the war in Iraq could become possible due to the disinformation campaign initiated by the Bush administration as part of the 'war on terror' frame to capture the minds of Americans as a way to conquer Iraq and retain the White House" (Castells, 2016, p. 563).

M. Castells was also one of the first who paid attention to the role of the Internet, which in postmodern society "remains a zone of choice of uncontrolled messages that extend the range of sources of information and disinformation, and replace the lack of trust with great diversity" (Castells, 2016, p. 563).

Another social and philosophical approach which makes an attempt to explain the disinformation processes is connected with the concept of post-truth. This term was chosen as the word of the year in 2016 because it is "demonstrating its impact on the national and international 
consciousness" (Oxford Languages, 2016). For postmodern discourse, the question of defining the concept of "post-truth" remains relevant as well. Over 30 years a study of changes in the concept of post-truth demonstrates that this "concept which began as a critique of the media establishment from an intellectual left position, was eventually turned against the very milieu it originated from" (Krasni, 2020).

The peculiarity of the information space during the Covid-19 pandemic is that the population was forced to learn medical terms and to understand scientific explanations. Ordinary citizens do not have the appropriate academic knowledge, so they are not always able to understand it, but they realize that they must follow the latest medical news in order to protect themselves from the new virus. Thus, the population begins to understand complex medical terms and processes (frequency of virus spread, types of tests and accuracy of testing, medical protocols, asymptomatic disease, etc.) (Huidu, 2020). In turn, this can lead to misperceptions, as people do not always use critical thinking to recognize true and fake messages.

Special mention should be made of the message formation on social networks, which has become a challenge for communication professionals and has demonstrated the strength of Internet communities influence that are able to distribute messages through repost (Allington \& Duffy \& Wessely \& Dhavan \& Rubin, 2020). This is a new communication format, when messages in a group are distributed by its members among other users of the network, so this information goes beyond this community information space.

There is also a thought that a panic attack during the Covid-19 pandemic confirms that population were zombified through the media and the Internet (Nerubasska \& Lopuha, 2020). Some authors believe that the question of authenticity can be solved within the framework of philosophy and theory of knowledge, they argue that "historical, political and social facts are more exposed to false interpretations and have more complex ladennes" (Nerubasska \& Lopuha, 2020, p.98).(Nerubasska \& Lopuha, 2020, p.98).

In Ukraine, a handbook entitled "Teaching practices to avoid the infodemic or Don't isolate yourself form truth Textbook" (Volosheniuk et al., 2020) has been developed specifically to properly cover pandemic events and fight fakes. The authors note that in times of global crisis, panic is exacerbated by "excessive emotional content of information messages and the incredible pressure of their number on the human psyche, which 
significantly reduces the ability to rationally perceive reality and make informed judgments and adequate decisions in everyday life" (Volosheniuk et al., 2020, p. 68). Features of fake messages are: absence of sources of information, the presence of grammatical errors, distortion of information (errors in names, positions, titles), lack of specifics (how much to drink water, what salt solution to gargle), high emotionality, unauthorized source of distribution, the presence of conspiracy references. Fakes about COVID19 distort information about the virus; contribute to panic; provoke chaos; cause distrust to people with special means and in special suits and to state and municipal institutions; form a feeling of fear about the insecurity of their houses and apartments.

In Ukraine, in addition to the Ministry of Health, social communication specialists and media professionals joined the fight against misinformation about COVID-19, emphasizing the use of official sources with reliable information. Creation of an Internet platform "On the Other Side of the Pandemic" (2020) is interesting as materials about Covid-19 are checked for veracity there. Also in Ukraine a number of information periodicals have created their own ratings of the most popular myths about the coronavirus.

Theoretical achievements of the information society have become the basis for explaining modern processes of spreading disinformation in social networks. Empirical researches confirm that in most cases, individuals spread the disinformation on social networks not because they have a purpose to harm someone, but because they can not distinguish the true and the false information (Pennycook et al., 2020).

We can see a similar trend in case of disinformation about Covid-19. The results of the international study of susceptibility to Covid-19 disinformation company and its influence on health-related implementation, which took place in Ireland, the United States, Spain, Mexico, and the United Kingdom, showed that despite the fact that most respondents do not trust the disinformation about Covid-19 as a whole, but some false messengers can represent "pose a potential risk to public health" (Roozenbeek et al., 2020).

Besides, there were some conspiracy theories which should be mentioned among the disinformation messengers about Covid-19, and they were spread on social networks. In the socio-philosophical context, it's actual the question that some part of the population refused to follow the rules of self-isolation, that could be explained their belief in conspiracy theories. The 
researches proved that social networks influence the formation of conspiracy beliefs and they do some harm to health-promoting behavior. This is also confirmed by the fact that "may be that older people are more likely to reject conspiracy beliefs and engage in health-protective behaviors in part because they make more use of broad cast media and less use of social media" (Roozenbeek et al., 2020).

The Covid-19 pandemic outlined new socio-philosophical issues regarding the adaptation of individuals to new living conditions. Modern researchers, analyzing the changes that took place in the social practices of individuals, predict that in a post-pandemic society the process of virtualization of social space will continue. These trends will influence "the emotional intensity of social interactions, especially inter personal ones, accompanied by a deconstruction of the idea of belonging group because even within these groups we already have - and we will have more and more - virtual relation ships" (Sandu, 2020). The virtualization of social space has also the effect that the virtual space has become the main source of information, which is also full of false messages.

In general, modern society is faced the problem of individuals' adaptation to a normal life after finishing the quarantine. Also "A sociality of people and theirs low return to collective forms of everyday life organization may slow down economic recovery" (Shi \& Yaroschchuk, 2020). Thus, the question of the impact of social isolation on the individuals' behavior, will manifest with spheres of society in future.

The grate amount of information messengers about Covid-19 is also a challenge for the media, which are strengthening the requirements for the verification of information sources, and which are responsible to society. An example of restricting the disinformation messages on social networks is "decision by Twitter, Facebook, and You Tubein late March to remove posts shared by Brazilian President Jair Bolsonaro because they included coronavirus misinformation was in our view an important moment in how platform companies handle the problem that a lot of misinformation comes from the top" (Brennen et al., 2020).

\section{The misinformation space in the media system}

The definition of information is discursive and has a semantic load depending on theoretical approaches. In modern science, we can set the following most common definitions of information as: information about 
something, receiving messages, reflecting diversity in any processes and objects (Dzioban, 2010).

Information can contain knowledge about the world, or vice versa, fiction and inaccuracies. Specialists in social communications study the technology of information creation and its influence on audiences with different socio-demographic characteristics. The impact of information on the population is actualized during non-standard social events that challenge society (Cantril, 1982).

Information and misinformation during the COVID-19 pandemic take on a new form, which experts have described as "infodemia" (World Health Organization, Infodemic Management - Infodemiology, 2020). It is "overabundance of information - some accurate and some not - that occurs during an epidemic. It can lead to confusion and ultimately mistrust in governments and public health response" (World Health Organization, 2021).

In the postmodernist conception of Jean Baudrillard, in his work "Simulacra and Simulation" (2013) it is possible to find a justification for the social processes of misinformation dissemination. Describing the activities of the media, J. Baudrillard notes that "we are in a space in which there is more and more information, and less and less meaning" (Baudrillard, 2013, p. 204). In fact, information does not always make sense, it is also capable of destroying its own content, communication and social. This is due to the fact that the information does not promote communication. On the contrary, it "is exhausted in the process of mise-en-scène of communication" and does not produce meaning, because "it exhausts itself in the process of the miseen-scène of meaning" (Baudrillard, 2013, p. 204).

Misinformation about Covid-19 is a "mise-en-scène of meaning" and a "mise-en-scène of communication" because it only creates an idea of meaning and is disseminated through various channels (traditional and new media), using photos and videos, emotional headlines and theses. The multiplication and acceleration of information dissemination creates a new space of "infodemia", which, on the one hand, partially reflects social information and copies the real situations.

Countries around the world have begun to fight disinformation using their own mechanisms. This experience is useful for creating cases to overcome the problem. They used blocking and banning false information, disseminating true information posted on official websites to overcome the spread of fakes. The World Health Organization has issued a number of 
recommendations to fight stereotypes about Covid-19 (World Health Organization, 2021).

Thus, the Ministry of Health of Ukraine posted official statistics on the number of patients in the country and recommendations to the public on the algorithm of action for suspected Covid-19 on its official website. On February 6, the site posted a publication on "7 common questions about the new coronavirus" (Official site of the Ministry of Health of Ukraine, 2020) which stated that the information about the new virus contained reliable data as well as rumors, the most popular of which were substantially debunked. These fakes mostly repeated the myths already identified by the WHO (it is safe to receive parcels from China; the new virus is not transmitted through fruit, for example, bananas; coronavirus is transmitted by airborne droplets from person to person, etc.).

\section{Fakes about Covid-19 in the information space of Ukrainian society}

In Ukraine, a number of fakes were based on misinformation from Western sources (helicopters will spray disinfectant; advice from Japanese and Taiwanese doctors on self-testing for coronavirus; people become infected with Covid-19 when tested; $5 \mathrm{G}$ towers kill an individual's immunity and spread Covid-19). These messages use manipulative technologies when the authors offer to distribute this text in order to save someone's life; or begin with a reference to the statement of the pseudo-expert. In some cases, photo fakes are used to intensify panic, which requires a separate study within the framework of visual communication.

The misinformation that was spread in the Ukrainian media concerned not only medical issues, but also the changes that took place in everyday life. Analysis of fakes posted on the platform "On the Other Side of the Pandemic" allows us to identify the following topics of fake messages:

1. The origins of Covid-19 (for example, Covid-19 was created artificially to kill Mongoloids), including "conspiracy fakes" (the coronavirus is a biological weapon).

2. Restrictions on the movement of certain categories of citizens in public places. For example, clinics refuse to accept people of retirement age; children must not go outside during the quarantine or parents will pay a fine for violating this decision.

3. Mask material and how to wear a mask on the face. Some reports have stated that the colored side of the mask is treated with a special substance that prevents germs from entering the airways, and the inner 
(white) side filters. That is why the mask should be worn with the white side to you, if you are a carrier of the virus. If you do not want someone to infect you - the mask should be worn with the white side out. Some sources have preferred neoprene masks because they protect against Covid-19 (neoprene fabric is used to make surfing and winter diving suits).

4. The situation with Covid-19 is used by fraudsters who, hiding under the guise of doctors, tried to seize citizens' savings (criminals wore a disinfectant suit and went from house to house).

5. Fictitious fines to be paid by citizens and businesses for violating quarantine requirements. Fake reports claimed that stores would be fined for unauthorized price increases. Citizens should always keep masks, gloves and antiseptics in their cars, and people will be fined for sending information about the coronavirus in messengers with possible arrest for up to 15 days. In some disinformation messages, a "COVID passport" was invented, which every citizen of the country should receive; those who fail to do so will pay a fine.

6. Contact with animals should be avoided as they carry the coronavirus. This fictional news was spread not only in the media and social networks, but also on billboards and city lights of the city. There is also the opposite fake that people who have pets at home have a lower risk of contracting Covid-19.

7. Pseudo medical recommendations with the use of certain drugs and tools to diagnose the Covid-19.

8. Statements of public authorities regarding the strengthening of the quarantine regime.

9. Situations with the spread of Covid-19 in other countries. Fake news from Western news sources were spread in Ukraine (a large number of deaths and those infected with the virus).

10. The readiness of Ukrainian society for the Covid-19 pandemic. Photos of Ukrainian hospitals that need repair and are not equipped with the necessary medical equipment. Impressive and exaggerated information about the significant number of infected people in Ukraine. The video, which shows a man coughing, being pushed off a bus, went viral. This is done to scare people and to spread panic among the population.

Misleading messages were formed on each of these topics, most of the fakes arose within the issues of pseudo-medical recommendations and manipulations with the statements of state bodies regarding the quarantine regime. We consider it necessary to examine them separately. 
Among the fakes related to medical topics, the recommendations for the use of certain medications have a special place. There is a widespread belief in the media that the authors of these rumors are pharmaceutical companies seeking to increase their profits. For example, Amixin and Arbidol are recommended for the prevention of coronavirus. Covid-19 can be treated with Anaferon and Ibuprofen should not be taken. Also people were offered to buy drugs from the coronavirus Proteflazid or Dekasan, the effectiveness of which has not been proven. Some reports said that Ukrainian doctors had found an effective cure for the coronavirus. Ukrainian specialists suggested treating Covid-19 with medical banks and vibrations of the human body.

Advice from pseudo-experts was also disseminated in the Ukrainian information space. There was a report that a doctor working at Shenzhen Hospital called his relatives and gave an explanation about the course of the disease. Despite the fact that the WHO constantly reminds that in the world there are no drugs for the prevention and treatment of coronavirus, new advice on the use of drugs is constantly emerging in the media.

Alternative medicine measures were also disseminated, claiming that they helped protect the body from Covid-19: gargling with vinegar and salt; consumption of ginger and garlic, vitamin $\mathrm{C}$ and lemon, hydrogen peroxide; inhalation of water vapor kills the coronavirus. Some fakes have been distributed in several waves in the Ukrainian media.

The following misinformation on medical issues regarding Covid-19 was also spread in Ukrainian media and social networks: coronavirus affects non-smokers more than smokers; beard increases the risk of coronavirus; coronavirus does not live on surfaces; people with a certain blood type are more likely to get Covid 19; there is a "coronavirus wind" that carries the virus, the population is urged to seal vents and kitchen hoods in apartments.

Misleading messages were spread in the Ukrainian information space, in which manipulations and fictitious references to state decisions and resolutions were used. Thus, it was noted that the Department of Health announced that citizens on benefits would be provided with services on free testing and would be supplied with free masks.

A number of mailings on social networks reported that citizens have the opportunity to receive financial assistance. For example, that the largest bank in Ukraine pays government aid in the amount of UAH 800 due to the spread of Covid-19. 
The population of the country was shocked by misinformation reports about the introduction of curfews (ban on being in public places at certain times of the day without specially issued permits and identity cards) in some regions. These messages came amid the state's celebration of the country's religious and state holiday (Easter Day). The fake that the Cabinet of Ministers of Ukraine has banned the celebration of this holiday has also become widespread. It should be noted that honoring these cultural and religious traditions during quarantine was discussed in the dialogue between the authorities and representatives of the All-Ukrainian Council of Churches, which imposed restrictions on mass religious events to prevent the deterioration of the epidemiological situation.

Thus, the media reported that a curfew was imposed in Zakarpattia, Volyn and Lviv regions during the celebration of Easter. Some publications referred to the video of the Head of the Lviv Regional State Administration Maksym Kozytsky. It was a recommendation to refrain from moving and being in public places so that people would maintain social distance and not form mass gatherings. In Transcarpathia and Volyn, it was recommended to introduce additional restrictive anti-epidemic measures during the holidays.

In the everyday life of Ukrainians there is a tradition to arrange picnics on weekends. Some sources have spread fakes that residents of the capital will be fined for a holiday with barbecues.

Fake rumors about the extension of the quarantine period in the country and the transfer of education in schools were constantly spread on social networks. Most of these messages did not indicate the source of the information, there was no official document, and were distributed in the Viber messenger application.

New living conditions on self-isolation with certain restrictions on social activity destroyed traditional practices and formats of communication. Misinformation not only contributed to the emergence of panic, but also was a "mise-en-scène of meaning", the meaning of an individual's new way of life.

\section{Conclusions}

The discussion of the reasons for the COVID-19 spread and mechanisms of combating misinformation about it within the interdisciplinary discourse contains theoretical and practical provisions that create a case with the implementation of the practice of combating fakes. In 
general, raising public awareness of certain topical issues will help develop critical thinking and prevent the spread of false information.

Misinformation in the information space of Ukrainian society during the COVID-19 pandemic was based on fake reports from Western sources. The fake messages that were spread in the Ukrainian media touched the following topics: the origin of Covid-19; restrictions on the movement of certain categories of citizens in public places; mask material and the way to wear a face mask; hidden fraudsters under the guise of doctors who are trying to seize the savings of citizens; fictitious fines for violating quarantine requirements; animals transmit and/or protect against coronavirus; pseudomedical recommendations for the use of certain drugs and measures to diagnose Covid-19; statements of public authorities regarding the strengthening of the quarantine regime; the spread of Covid-19 in other countries; inadequate state of readiness of Ukrainian society for the Covid-19 pandemic.

The population of the country perceived misinformation uncritically, without checking the sources, as they moved in the direction of a new space of individual life, and created a "mise-en-scène of meaning". The population's gaps in the knowledge of medical theories and academic terms were filled by these vulnerable and influential misinformation messages, which in the postmodernist tradition hid the reality with fictional messages.

The Covid-19 pandemic demonstrates one of the important features of a postmodern society, which was also identified by the theorists of information society, these are the simplification of information production and its distribution. A number of important social events were supplemented by false information which is send out intentionally or because of ignorance of the users. Disinformation becomes a part of the worldview of the individual, that makes an obstacle to the development of a society as a whole.

\section{References}

Allington, D., Duffy, B., Wessely, S., Dhavan, N., \& Rubin, J. (2020). Healthprotective behaviour, social media usage and conspiracy belief during the COVID-19 public health emergency. Psychological Medicine, 1-7. https://doi.org/10.1017/S003329172000224X

Baudrillard, J. (2013). Simulacra and Simulation (O. Pechenkina, Trans.). Tula polygraphist. (Original work published 1981) 
Misinformation in the Information Space of Ukrainian Society during the ... Iryna DENYSENKO, et al.

Brennen, J. S., Simon, F., Howard, P. N., \& Nielsen, R. K. (2020, April 7). Types, Sources, and Claims of COVID-19 Misinformation. Reuters Institute for the Study of Journalism. https:// reutersinstitute.politics.ox.ac.uk/typessources-and-claims-covid-19-misinformation

Cantril, H. (1982). The Invasion from Mars. A Study in the Psychology of Panic. Princeton University Press.

Castells, M. (2016). Communication Power (N. Tylevich, Trans.).HSE University. (Original work published 2009)

Dzioban, O. P. (2010) Information security in the problem field of socio-cultural reality: monograph. Maidan.

Huidu, A. (2020). The Social Responsibility of Researchers in Combating Fake News and Conspiracy Theories During a Pandemic. Postmodern Openings, 11(1Supl2), 39 - 48. https://doi.org/10.18662/po/11.1sup2/138

Infodemic Management - Infodemiology (2020). Official site of the World Health Organization https://www.who.int/teams/riskcommunication/infodemic-management

Krasni, J. (2020). How to hijack a discourse? Reflections on the concepts of posttruth and fake news. Humanities and Social Sciences Communications, 7 (1). https://doi.org/10.1057/s41599-020-0527-z

Nerubasska, A. \& Lopuha, O. (2020). Pandemic Panic in Information Space: the Fact and its Ladennes. Postmodern Openings, 11 (1Supl2), 93-99. https://doi.org/10.18662/po/11.1sup2/144

Official site of the Ministry of Health of Ukraine. (2020). 7 common questions about the new coronavirus https://moz.gov.ua/article/news/7-poshirenih-pitan-pronovij-koronavirus

On the Other Side of the Pandemic. (2020, March 2020). Fake: To avoid infection, wear a mask with the white side facing out. On the Other Side of the Pandemic. https://coronafakes.com/fake/feyk-shchob-vas-ne-infikuvaly-trebanosyty-masku-biloiu-storonoiu-nazovni

On the Other Side of the Pandemic. Platform on which information is quickly checked and fakes about the coronavirus are refuted. (2020). https://coronafakes.com/

Oxford Languages. (2016). Word of the Year 2016. https://en.oxforddictionaries.com/word-of-the-year/word-of-the-year$\underline{2016}$

Pennycook, G., McPhetres J., Zhang Y., Lu J.G., Rand D.G. (2020). Fighting COVID-19 Misinformation on Social Media: Experimental Evidence for a Scalable Accuracy-Nudge Intervention. Psychological Science, 31(7), 770- 780. https://doi.org/10.1177/0956797620939054 
Roozenbeek, J., Schneider, C. R., Dryhurst, S., Kerr, J., Freeman, A. L. J., Recchia, G., Van Der Bles, A. M., \& Van Der Linden, S. (2020). Susceptibility to misinformation about COVID-19 around the world: Susceptibility to COVID misinformation. Royal Society Open Science, 7(10). https://doi.org/10.1098/rsos.201199

Sandu, A. (2020). Pandemic - Catalyst of the Virtualization of the Social Space. Postmodern Openings, 11(1Sup2), 115-140. https://doi.org/10.18662/po/11.1sup2/146

Shi, Y., \& Yaroschchuk, L. (2020). Post Corona Society: How to Teach People be Social Again. Postmodern Openings, 11(1Sup2), 169-176. https://doi.org/10.18662/po/11.1/sup2/149

Toffler, A. (2004). The third wave. Moscow: Publishing house AST. Toffler, A. (2004). The third wave (S. Barabanov, K. Burmistrov, L. Burmistrova, Z. Zaritovskaya, E. Komarova, N. Krotovskaya, V. Kulagina-Yartseva, A. Mikisha, I. Moskvin-Tarkhanova, E. Rudneva, K. Tatarinova, N. Khmelik. Trans.) Moscow: Publishing house AST.

Volosheniuk, O., Yevtushenko, R., Ivanov, V., \& Kulakov, A.(Eds.). (2020). Teaching practices to avoid the infodemic or Don't isolate yourself form truth Textbook. AUP, Internews-Ukraine, Center for Free Press.

World Health Organization (WHO). (2021, July 1). Coronavirus disease (COVID-19) advice for the public. https://www.who.int/emergencies/diseases/novelcoronavirus-2019/advice-for-public 